\title{
Kidney Hemangioma
}

National Cancer Institute

\section{Source}

National Cancer Institute. Kidney Hemangioma. NCI Thesaurus. Code C159211.

A rare hemangioma arising from the kidney. 